\title{
Social Consensus, Democratic Conflict: The Debate on the Decriminalisation of Abortion in Uruguay
}

\author{
Lilián Abracinskas and Alejandra López Gómez
}

Since 1985, the year in which democracy was restored after 12 years of military dictatorship, initiatives attempting to amend the Penal Code in order to decriminalise the practice of abortion in Uruguay have been introduced in every term. The current law, enacted in 1938, establishes that abortion is always a crime, but that judges may decide to mitigate the punishment or even acquit the defendant under some mitigating circumstances, as long as the procedure is performed by a medical doctor during the first trimester of gestation, except when the woman's life is at risk. ${ }^{1}$ During the years in which the law has been in force, it has not been applied because the conditions for it to be implemented - providing access to services performing abortions under the circumstances established - have never been met (Abracinskas and López Gómez 2004). The fact that abortion is always defined as a crime and the fact that the admission of mitigating and acquitting circumstances is ambiguous make this a law that is impossible to implement (Dufau 1989).

The current law has proved to be ineffective in discouraging the practice. Very few people have been convicted for the crime of abortion and the termination of pregnancies is still a very widespread practice in the country. ${ }^{2}$ The cases involving convictions are almost exclusively connected to situations in which the woman involved died. This punitive law has simply encouraged the clandestine practice of abortion, which, most of the time, is carried out under unsafe conditions, and which continues to take a heavy toll on the health and lives of women. It would seem, then, that the main goal of criminalising abortion in Uruguay is not to reduce the practice, but to impose an atmosphere of social condemnation and disapproval deeply rooted in the double standard aimed at blaming and subjugating women who have had an abortion.

Over the last 20 years, support for the legalisation of abortion has grown. This has gone hand in hand with the process of recovery and consolidation of democratic life in the country, influenced by tensions inherent to the process of deep cultural transformation experienced by Uruguayan society. Understanding the struggle for safe, legal abortion in Uruguay, then, needs to be set within the broad context of the construction of democracy, citizenship and social participation.

\section{Legal initiatives}

Five bills aimed at decriminalising/legalising abortion have been discussed in the Uruguayan Parliament since 1985. This shows that there are real efforts to adjust regulation to reality, and to social demands. These initiatives have progressively attempted to approach the issue comprehensively, introducing measures to establish universal access to sexual education, contraceptive methods and to encourage responsible motherhood and fatherhood. All legislative initiatives have been based on an interest in tackling the health and social issues bound up with abortion - such as its clandestine and unsafe practice. They also attempted to promote measures that consolidate the democratic life of the country, recognising and respecting the diversity of sets of 
values existing in the society while protecting individual freedom in the exercise of sexuality and control of reproductive capacity. ${ }^{3}$

This kind of legislative response, one that respects human rights and is sensitive to people's demands and needs, is still pending. The negative result met by different bills during four terms of government in the post-military dictatorship era can be explained by the dominance of the logic of political compromise the electoral cost and/or the influence of powerful sectors bent on maintaining the status quo and the hegemonic dominance of their own beliefs and values. Yet they have had to contend with women's and feminist organisations which, in alliance with other partners - trade unions, academic institutions, non-governmental organisations (NGOs), religious groups and others - have maintained the social debate on abortion and turned this right into a social demand. With the explicit commitment of representatives and senators in the current government, this pressure has brought about a new bill that was passed in the Senate on 6 November 2007. The announcement made by the President of the Republic and prestigious oncologist, Dr Tabaré Vazquez, that he will veto any bill that legalises abortion passed by parliament on the grounds of conscience, was an attempt at hindering the legislative debate. But it failed at preventing it. Today, the people wait for the bill to be completely approved by the Uruguayan Parliament in the House of Representatives. From that moment on, all efforts and social claims must be focused on the Executive Branch, to enact the law passed and allow for it to be promptly implemented.

\section{Control and freedom in a secular state}

The control of the state over people's privacy, sexuality and reproduction has been naturalised so many times and in so many different ways, that it is no longer considered a dilemma - as if the laws of society were natural laws, like the laws of physics (Ávila 2003). Many of the rules governing the way people conduct their daily lives have been established by an elite of powerful men who have imposed and continue to impose their own beliefs over respect for coexistence in a democratic state (Abracinskas and López Gómez 2001). Uruguay's identity as a country is deeply rooted in the fact that it is a secular state. Yet, asserting the idea of a secular state is to break with an authoritarian tradition, which has systematically blocked the public discussion of long- standing issues that require a response that is careful and that necessarily provides for the complexities that it intends to manage.

The political stand taken by the main leader of the left-wing parties in the country provokes reactions in the core of the progressive social movement which creates a conflict in the bond between social forces, political parties and the government's ability to represent, to channel proposals for change and to answer to the people's demands. Pluralism, freedom of conscience and diversity, and equality are secular ideas. These ideas, which include the right to religious freedom, emphasise that there should be no privilege of any one social group over another. It is these principles that are at the root of real possibilities of democratic coexistence (Güezmes 2006).

The state is under an obligation to respect and defend the individual guarantee of freedom of thought, religious freedom, freedom of worship and equality of everyone before the law. Authorities must respect and enforce the plural and democratic order of society, designing policies that, within the context of respect to human rights, supervise the obligation of public officers to make decisions based on regulations and not on their personal beliefs.

\section{From feminist claim to social demand}

Uruguayan society has allowed itself to speak openly about these issues - which were once unspeakable as a result of a strong and sustained intervention by social parties. This has boosted ability and willingness to reach new consensuses around the defence and respect of everybody's right to decide in the field of sexuality and reproduction.

There are several reasons why new social consensuses are reached on issues that take place amidst struggles and tensions. The fact that unsafe abortion continues to be a social problem, together with the fact that it is still an issue in the health, social, legislative and media fields, are, in our opinion, fundamental. Such reasons must be placed within the growing process of social acknowledgement and legitimating of the sexual rights and reproductive rights inside an agenda founded on the universality, integrality, and indivisibility of human rights. The rise in the number of women's deaths in 2001, for reasons connected to the unsafe practice of abortion, occurred simultaneously with the worsening of the economic crisis in the country and 
the rise in the number of people living under conditions of social marginalisation and exclusion. $A$ prompt social reaction took place, and comprehensive responses for the prevention of unwanted pregnancies were demanded. In this context, the work of more than 20 years by women's and feminist organisations gained public recognition (Abracinskas and López Gómez 2007a,b).

The National Coalition of Social Organisations for the Defence of Sexual and Reproductive Health, created in 2003, sought to articulate feminist, trade union, religious, professional, academic, human rights, sexual diversity and youth organisations, and built an alliance around this issue without precedent in the country. Then followed public announcements of support from the Board of the Universidad de la República and the Sindicato Médico del Uruguay (Medical Association of Uruguay); both institutions enjoy great political and social legitimacy. Consensus among these parties was based on the fact that the bill was comprehensive, and on the relevance of recognising unsafe abortions as a public health, equity and social justice issue. Moreover, the agreement was supported by the claim that sexual and reproductive rights are fundamental human rights and that women have the right to decide with regard to their own bodies.

Abortion as a dimension of personal freedom in the right to decide when to have children, how many to have and the number of years between them, was introduced in the country's political agenda, among the 'great national issues'. Some indicators of this process are the results shown by public opinion polls carried out in the country on this topic since 1985. The shift in public opinion in the last few years is significant: starting in the 1980s, with 25 per cent of people accepting a woman's right to decide on voluntarily interrupting a pregnancy during the first trimester and reaching the approval of 65 per cent of people in 2007 (Selios 2007).

\section{Quality of democracy}

The conflict about decriminalising abortion has become one of the problems that the left-wing government has to manage, bringing into question: 'representation in representative democracy', especially with regard to the ability to respond to demands that include a clear claim for autonomy and freedom of choice and respect for women's rights. The announcement of the presidential veto has hindered the parliamentary debate. It has also blocked the actions aimed at dealing with the consequences of the performance of clandestine abortions. A government which has focused its concerns on taking care of the poorest population living under conditions of social vulnerability, does not consider that failing to respond to the occurrence of unplanned/not sought/unwanted pregnancies, which lead thousands of women to risk their lives and their integrity by having to resort to illegal and clandestine procedures, is an injustice or a contradiction (Abracinskas and López Gómez 2006).

In spite of this, representatives of the governmental party in the Chamber of Representatives have decided to give greater impetus to the bill and to vote in favour of it. The group of parliamentarians decided to include a new article in the bill which says that 'in case that the bill would be fully approved, the law begins to be implemented in March, 2009'. Parliamentarians adopted this strategy to deter the President of the Republic from vetoing it, taking into account that there will be national elections in October 2009, and Dr Tabaré Vazquez cannot be reelected for the position. Unfortunately, the president has rejected this proposal and continues to insist on vetoing the specific chapters regarding abortion. However, according to the Uruguayan Constitution, it is not the president himself who alone has the capacity of veto. Only the Executive Power is able to veto a bill and this is shared between the president and the Cabinet of Ministers. Under these circumstances, the political situation is much more complex. If the veto was imposed on the Defence of the Right to Sexual and Reproductive Health bill, it would generate a great contradiction inside the governmental party, because the very votes in the parliament which permitted the approval of the bill are those of the same party that constitutes the executive power.

Feminist and women's organisations and their partners have made public their intention to work very hard to secure the full approval of the bill, including the articles related to the legalisation of abortion. This is a non-negotiable issue. Many of the Uruguayan social organisations that continue the fight for this legal change are working on expanding citizen engagement, and on citizens' empowerment to demand conditions and guarantees for the full exercise of their rights. This thick fabric of society and the institutional networks built around the right 
to an abortion will have to make authorities listen to their voice, as a means of social pressure. In this sense, the lack of specific mechanisms of direct participation is an obstacle for society to resolve this conflict present in the democratic system.

Latin American feminist and women's organisations have fought for the right to a safe and legal abortion for decades. Throughout these years, alliances and articulations with diverse groups from the social, political, professional and academic worlds have been built and strengthened. As a consequence, what originated as a feminist demand became a social demand and a matter of concern for a great variety of parties. International law supports these claims. In fact, international legal instruments on human rights and authoritative interpretations of these instruments, written by bodies made up of qualified experts from the United Nations, conclude that access to safe and legal abortion services is a key element to fulfilling women's human rights in general, including their reproductive rights and also those connected with their inherent human condition (Human Rights Watch 2006).

\section{Notes}

1 The law provides for four mitigating circumstances: rape, family honour, economic hardship and when the mother's life or health is at risk.

2 One recent report puts the number at 33,000 abortions a year (Sanseviero 2003).

\section{References}

Abracinskas, L. and López Gómez, A. (eds) (2007a) Aborto en Debate. Dilemas y Desafíos del Uruguay Democrático. Proceso Político y Social 2001-2004 [Debating Abortion. Dilemmas and Challenges in a Democratic Uruguay. The Social and Political Process, 2001-2004], Montevideo: MYSU

Abracinskas, L. and López Gómez, A. (2007b)

'Problemas Complejos, Intervenciones Integrales. Aborto Inseguro, Mortalidad de Mujeres, Reducción de Riesgos y Daños y Ejercicio de Derechos' [Complex Problems, Comprehensive Interventions: Unsafe Abortion, Maternal Mortality, Risk and Harm Reduction and the Exercise of Rights], in L. Briozzo (ed.), Iniciativas Sanitarias Contra el Aborto Provocado en Condiciones de Riesgo [Public Health Initiatives Against Unsafe Abortion], Montevideo: Arena
In order to make progress in the promotion, respect and creation of guarantees for the exercise of sexual rights and reproductive rights, Uruguay has some unfinished business to settle: to adjust its legislation to the growing social demand to decriminalise abortion. This legal change will constitute the recognition of women's rights to choose and it will also provide adequate support for professionals acting in this field. Recently, the Chamber of Representatives has been discussing the bill on the Defence of the Right to Sexual and Reproductive Health. Uruguayan society is monitoring the political debate. Most of the principal actors of the democratic system in the country have been attending it. It is a great opportunity for Uruguay and for Latin American countries to push for the recognition of sexual and reproductive rights as human rights and to have the guarantees for women's rights to decide. All democratic people and organisations around the world should be paying attention to this process. If Uruguay wins, all women win. If Uruguay has a law that legalises abortion, it will be a great advance towards having a more and better democratic system and society.

3 This has been especially the case in the two most recent bills: the Defence of Reproductive Health Bill (2002-2004) and the Defence of the Right to Sexual and Reproductive Health Bill (2007).

Abracinskas, L. and López Gómez, A. (2006) 'Análisis Feminista del Debate Social Sobre el Aborto en Uruguay' [Feminist Analysis of the Social Debate on Abortion in Uruguay], in S. Checa (ed.), Realidades y Coyunturas del Aborto: Entre el Derecho y la Necesidad [Abortion Realities and Key Moments: Between Rights and Necessities], Buenos Aires: Paidós Abracinskas, L. and López Gómez, A. (2004) Mortalidad Materna, Aborto y Salud en Uruguay. Un Escenario Cambiante [Maternal Mortality, Abortion and Health in Uruguay. A Changing Scenario], Montevideo: MYSU

Abracinskas, L. and López Gómez, A. (2001) 'Los Derechos Sexuales y los Derechos Reproductivos en la Arena Política. Estrategias de Advocacy Desde la Sociedad Civil Organizada' [Sexual and Reproductive Rights in the Political Arena. Advocacy Strategies from Organised Civil Society], 
presentation at the regional seminar ONG y Gobernancia [NGOs and Governance], Programa MOST-UNESCO, Montevideo

Ávila, M.B. (2003) 'Sexualidades e "Política" na Perspectiva Feminista' [Sexualities and 'Politics' in Feminist Perspective], in R. Parker and S. Corre (eds), Sexualidad e Política na América Latina [Sexuality and Policy in Latin America], Río de Janeiro: ABIA

Dufau, G. (1989) Regulación Jurídica del Aborto en el Uruguay [Legal Regulation of Abortion in Uruguay], serie documentos, Montevideo: GRECMU

Güezmes, A. (2006) 'Estado Laico, Democracia y

Aborto' [Secular States, Democracy and

Abortion], in S. Checa (ed.), Realidades y Coyunturas del Aborto: Entre el Derecho y la Necesidad [Abortion
Realities and Key Moments: Between Rights and Necessities], Buenos Aires: Paidós

Human Rights Watch (2006) International Human Rights Law and Abortion in Latin America, New York: HRW

Sanseviero, R. (2003) Condena, Tolerancia y Negación El Aborto en el Uruguay [Condemnation, Tolerance and Negation. Abortion in Uruguay], Montevideo: CIIP/NNUU

Selios, L. (2007) 'La Opinión Pública, la Democracia Representativa y el Aborto' [Public Opinion, Representative Democracy and Abortion], in L. Abracinskas and A. López Gómez (eds), Aborto en Debate. Dilemas y Desafíos del Uruguay Democrático [Debating Abortion. Dilemmas and Challenges in a Democratic Uruguay], Montevideo: MYSU 